Development or HIgh-Strength Martenslte by Age-Hardenlng of Coherent Intermetallic Preclpltates

A.S. Schulz-Boenken, H.P. Hougardy, Max-Planck-Instltut far Elsenforschung, DQsseldorf, FRC

Introduction

Only steels wlth a lath artenstte alcrostructure offer a coablnation of hlgh strength and $800 d$ ductllity. By a therwo cochanlcal treatwent tho wechanlcal propertles can oven be Improved to a tenslle otrongth of 920 MPa and a transitIon temperature of $-160^{\circ} \mathrm{C} / 1 /$. These values could be achleved by a lath martensite contalning 2 wts Mn, 2 wts $\mathrm{Cr}, 1$ wts Mo and 1 wts $\mathrm{ML}$ [818. 1]. To garantie a complete lath artenslte alcrostructure, the carbon content has to be Ilalted to 0.03 wts. whlch is too low to enable an evident increase in atrength oy preclpltation or No- or TI-Carbonttrates .

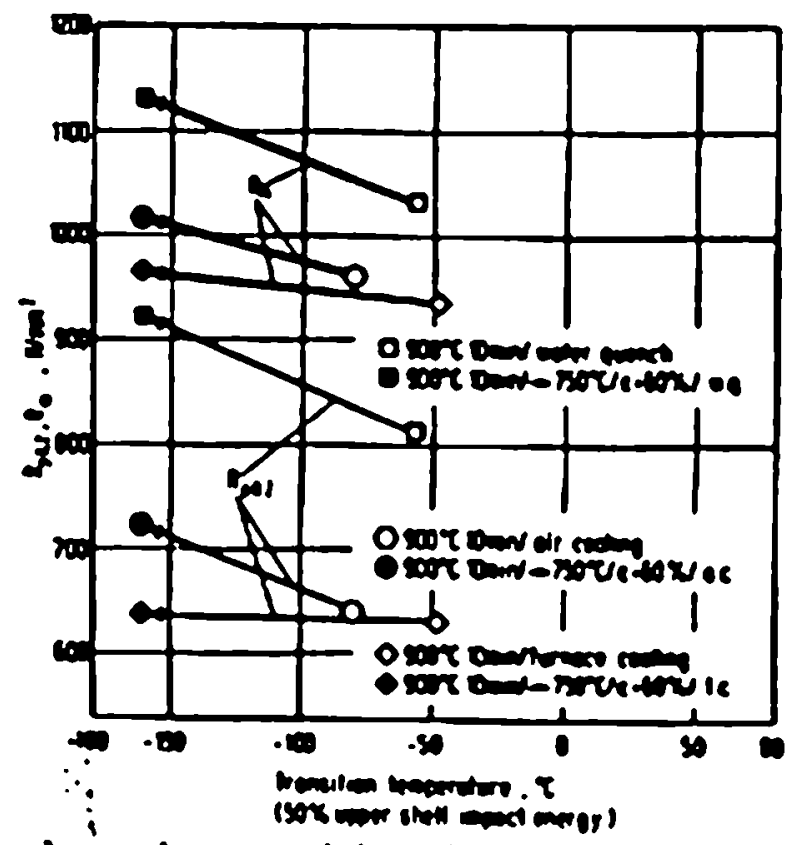

F18. 1: Mechenlcal valuẹs laprovod by therwo mechanlcal treatment of lath martonsite. $0.03 \& . \mathrm{C}, 0.5 \& \mathrm{SI} .28 \mathrm{Mn}, 2 \& \mathrm{Cr}, 1$ \& $\mathrm{Ml}, 1$ \& Ho aftor $/ 1$

The only way to laprove tenslie strength In thls steel. wlentn an acceptable loss of toughness, Is the ege-hardening of lath artensite by interactallic phases. Ago-hardenlng by Incoherent Interasallle partlcles, Ilko In maraglng oteels, requires a high degree or supersaturation of alloying elements and as nucleatlon 10 connected with lettlce defects, only inhowogeneous procipltation, alinly at graln boundarles, oan be achiered. Contrary, coherent prectpltates oring about a reankkable hardness increment even in low alloyed steels. Their

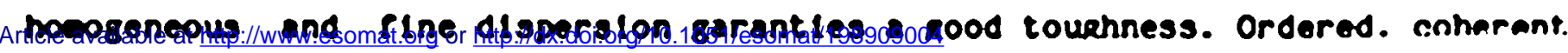


particles Increase the flow stress even wore than coherent particles, which can be sheard by single dislocations, as a hlgh antl-phase boundary energy in ordered particles requires the formation of superdislocations. Furthermore, these phases have a low growth rate, stabllising thelr coherency.

In ferrite, it is possible to achleve a conslderable hardness increwent with small additions of $S L$ and $T I$ by the preclpltation of Fe ${ }_{2}{ }_{1} T I$. Thls phase has a $L_{1}$ structure, belng closely related to $\mathrm{DO}_{3} \mathrm{Fe}_{3} \mathrm{Sl}$ with twlce the lattlce parameter of the Iron matrix /2/. As SI and TI restrlct the $\gamma$-Phase at $\mathrm{hlgh}$ temperatures. Mn and NI has to be added to achleve an ent1re a-r transformation and. after cooling, a subsequent transformation Into lath martensite. It has been posslole to develope a varlation or steels with relatlvely low additions of $2-4$ wts SI and TI and 2-W wtS $\mathrm{MI}$ and $\mathrm{Mn}$.

\section{Mechantcal Properties}

Investlgatlons to optlolse the cherical analysis and the heat treating paradeters have been carrled out to ensure a) total transformation Into $r$. b) surf1clent solubllitiy of the alloying elements to garantle maxlmum age-hardentng and c) minlmal grain growth. It was found, that spoclwens austenltised for 30 win at $1100^{\circ} \mathrm{C}$ orfer the hlghest hardness increment and a rine gralned alcrostructure, so that both, good ductllity and hlgh strength could be expected.

An adequate age-nardening is possible in the temperature interval between $400{ }^{\circ} \mathrm{C}$ and $700^{\circ} \mathrm{C}$. $500^{\circ} \mathrm{C}$ is the most sultable aging-temperature for wost or the alloys, achleving a satisfactory maxlour hardness of $560 \mathrm{HV}$ within an acceptable annealing $t$ lme of 2 hours. The hardness decreases only after wore than 22 hours of anneallng, whlle the hardness of a non-hardenable lath martensite did not have any alteration in hardness during annealing below $600{ }^{\circ} \mathrm{C}[\mathrm{Plg} .2]$.

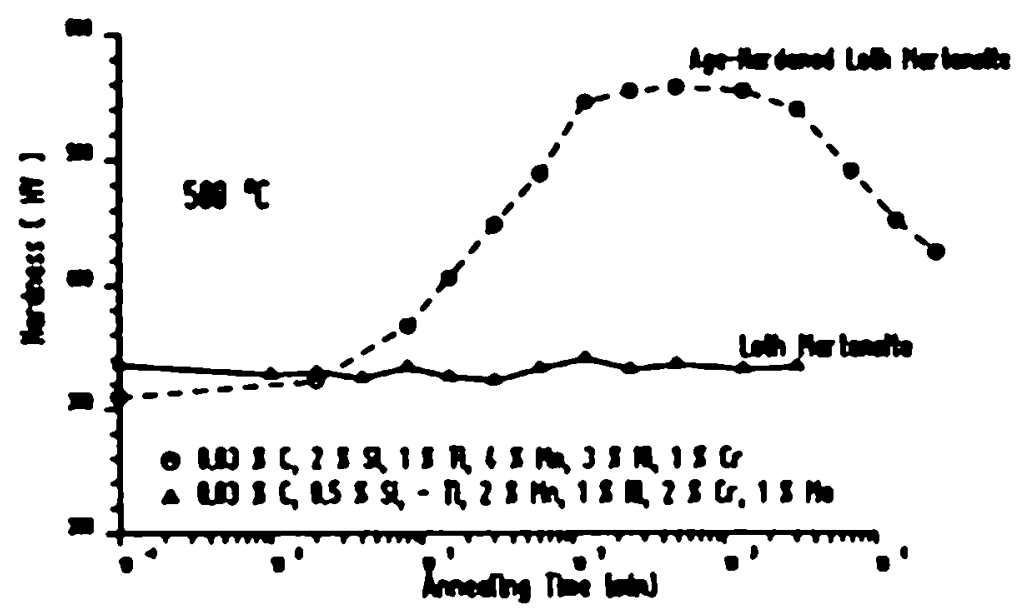

F1g. 2: Varlation of hardness with aging timo of age-hardened lath martensite 
Compresston tests shoved, that with increasing ennoaling time the tonsile otrength and hardness rloe to aximuo of $1800 \mathrm{MPa}$ 1.0. $560 \mathrm{HV}$. whlle the totsl -longation, as an Indicalion of ductility. decreases rran 658 to 158 . In ene orer-ased condition. as the elongation la plsing. the censlle strengeh and hroness decrease rapldiy. while the ultioute strencth realins at a high level [r18. 3]. The tenst10 strength can be ratsed to alcost the value of araging stedlo, whlle the toughnose of the hlgh alloyed maraglng ateols can not qulto be roschod. Speclmens at posk-hardness and underaged spoolmons showed aftor coapression distinct ellp oteps so that a coarse distribution of slip bands can be expected as reason for the low values of ductllity.

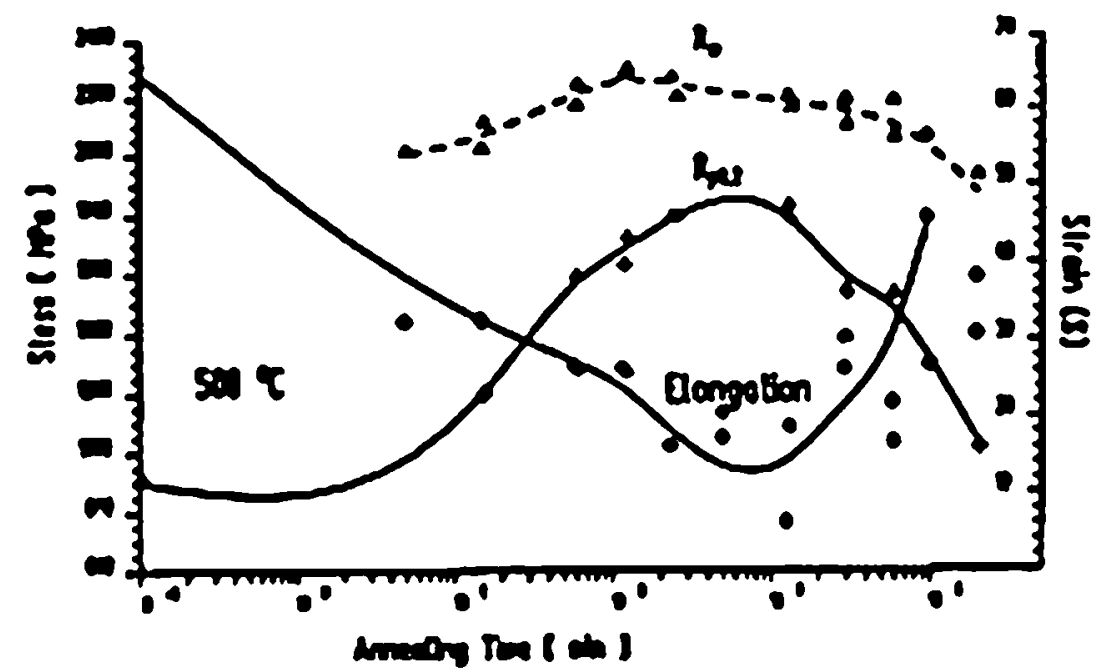

F18. 3i Varlation of exchantcal velues wlth agelng tles. wesured in coopresslon rest.

Fractoprapiy of aced opocteons after coopression ohowed a calnly britlel fractured surface. Only opecteens in the overaged atate had small parts wlth traces of plastle flow. The orlttel fracturs were ealniy intercristalline but also transcristalline, wheroby the Intercolstalline cracks could not be related to particles or phases on graln bouncarles.

Thermo Mechantcal Troatmint (THT)

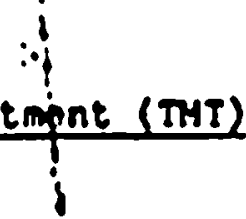

The thorwo mechanlcal treateent. mich was deveioped for these steels, wakes it posslole to transfora the deforaed austentte vithout prlor recrlstalisation into a hichly destorted lath artenslte [fle. 1]. To ensure sufflelent solld solut lon of the alloying elemonts at atill acceptable awtentte grain sizo. the austentelsation was $11 \mathrm{mlt}$ d to $30 \mathrm{minutes}$ at $1100^{\circ} \mathrm{C}$. A hot deforation rate of - 1 and even -1.510 posalble without cracklng, if tho proolpltation procoss, whlch causes embrittelmont. was evolded after MT by instenteneous water-quenching. The deforation teaperature could be reduced to $700{ }^{\circ} \mathrm{C}$. 


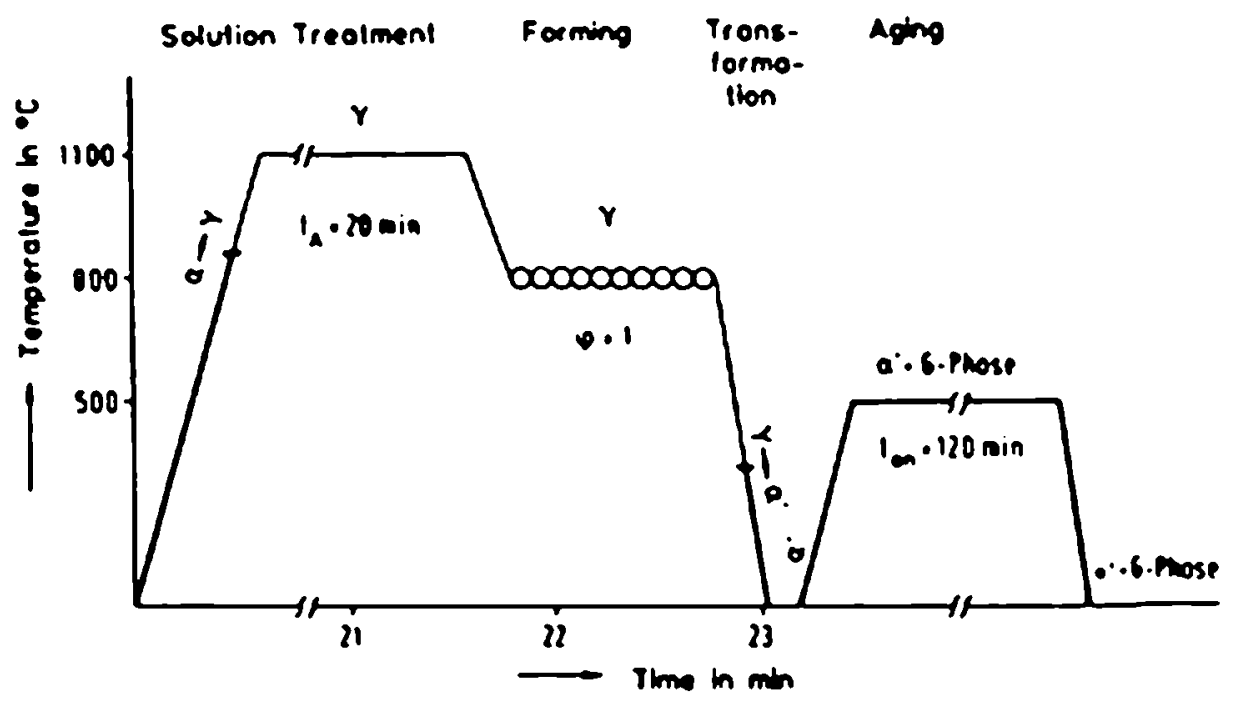

F18. 4: Schematic presentation of the spectally developed TMT.
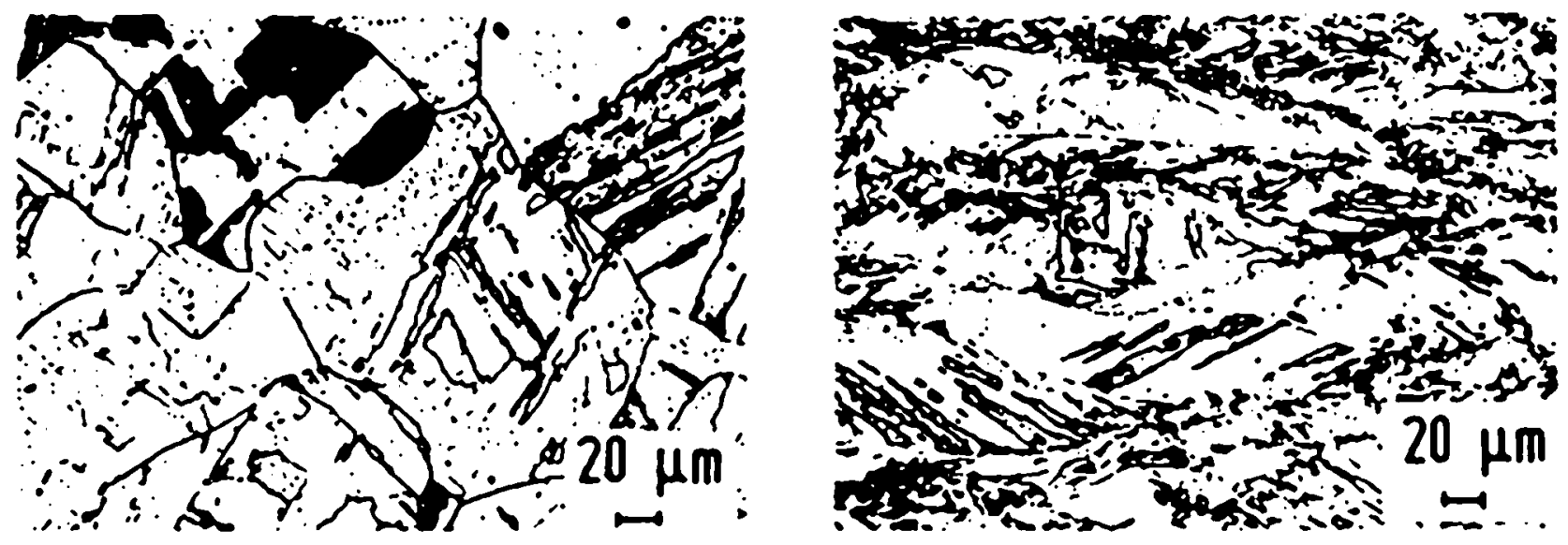

F18. 5a: M1crostructure without MIT.

F18. 50: Hlcrostructure after TMT.
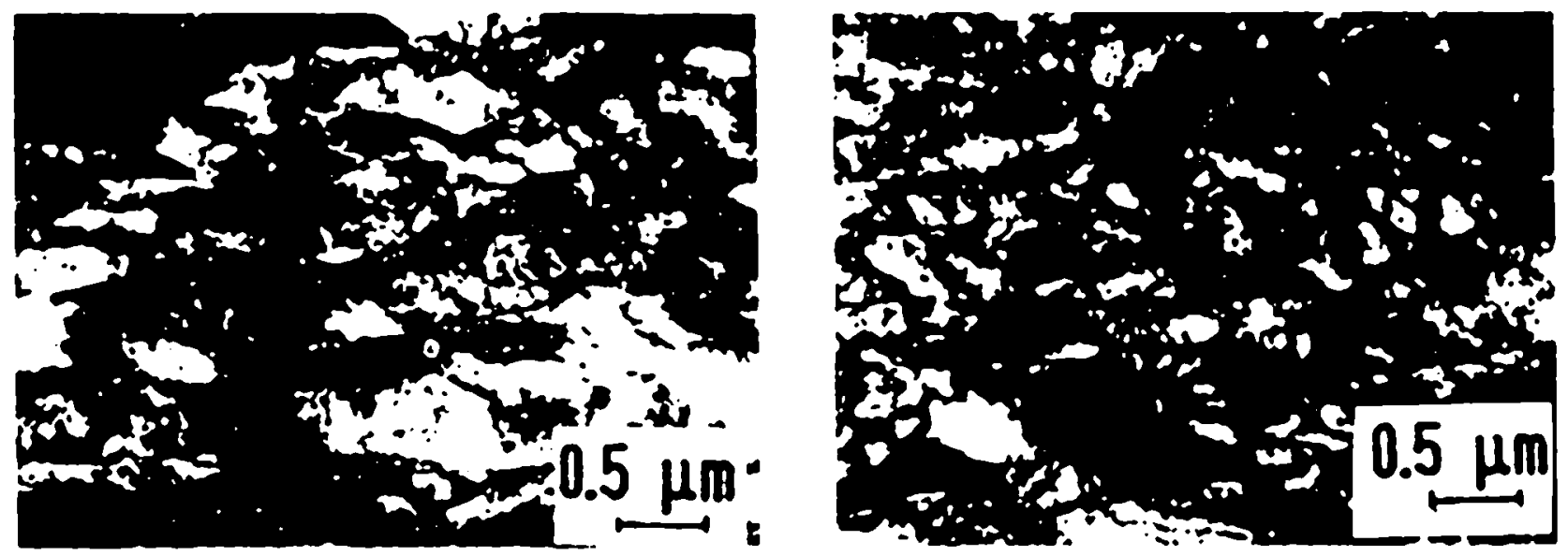

F1g. 6a: Electron mlerograph of

F18. 60: Electron mlcrograph of lath lath martenslte olcromartensite wlcro-structure structure wlthout TMT. after TMT. 
The olcrostruoture of thermo mochanlcal treated specimens show rlatt, pancake-shaped prlor austenlte gralns. Plner pecket slze [r18.5a-b], shorter laths and a higher dislocation density than those without therwo wechanlcal treatwent [PIg. 6a-b]. The influence of the MT on the hardness 18 relatively sall. The hardness increases raster and the eaxlmu hardness is higher than without TMT [P18. 7]. In compression tests the save effect on the 0.28 proof stress was measured, whlle the ultimate tenslle otrength is hardly influenced [818. 8]. The elongation, as a criterton for ductlltty, is littlo loproved by MI. but the besurements show olentflcantly lower standard deviation after IMT [P18. 9]. To conclude, the Increase in ductllity by MT wasured for the baslc lath eartenslte, whlch 15 due to a hasogeneous and fine lath otructure and hlgh, howogeneous dislocation denslty, could not be achleved in age-hardened lath martenslte by an even more optlmised therwo mechanlcal treatmont. It can be supposed that the influence of the preclpltetion hardening doalnates the influence of fining the lath structure.

\section{Examination of the precipltates}

In electron wicroscoplcal Investlgatlons of the now $N I$ and Hn containing marten-

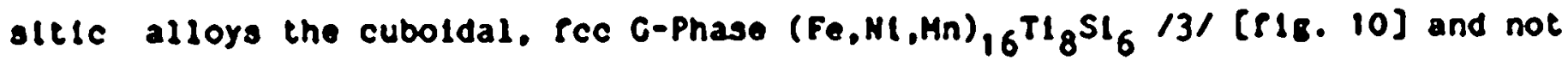

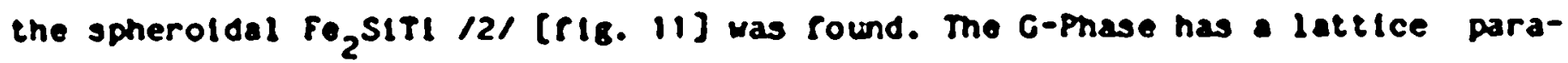
weter four tlass of that of ferrite, 13 also coherent to the matrix and seess to be a cooplex version of the $\mathrm{DO}_{3}$ structure, composed of $8 \mathrm{DO}_{3}$ undt cells $/ 4 /$.

The preclpltates are einely dispersed and nomogeneously distributed in the atrix. As they are conerent. thelr orlentation is dependent on the watrix orleniation [rig. 12]. The preclpltates do not seed to bo nucleated at dislocatisns, although: In graln boundarles larger preclpltates are found [8lg. 13]. They become coarseri with inoreasing annealing tiwe. Denuded zones can not be observed. Thls arrangement of particles oan bo explained by homogeneous nucleation. The different slze may be caused by faster diffusion in the grain boundary than in bulk materlal.

To Investlgate the Influence of the partlcle slzo on the hardness. speclwens at characteristlo stages of the ageing process at $500^{\circ} \mathrm{C}$ are analysed. At the aaxiwum hardness after 2 hours anneallng at $500^{\circ} \mathrm{C}$. the average partlole dtameter 18 less than $5 \mathrm{~nm}$. While after an annealing $t 1$ wo of 22 hours, at the begining of the hardness curve's decline, the dlaneter is only slightly wore than 5 n.. In 


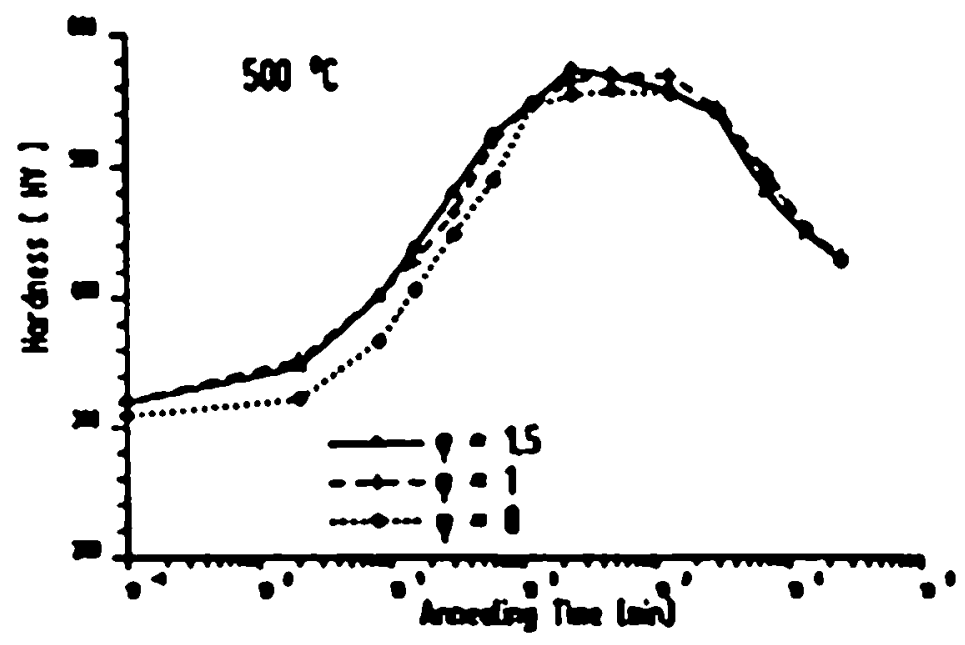

F18. 7: Varlation of hardness wlth agelng time and deformation rate.

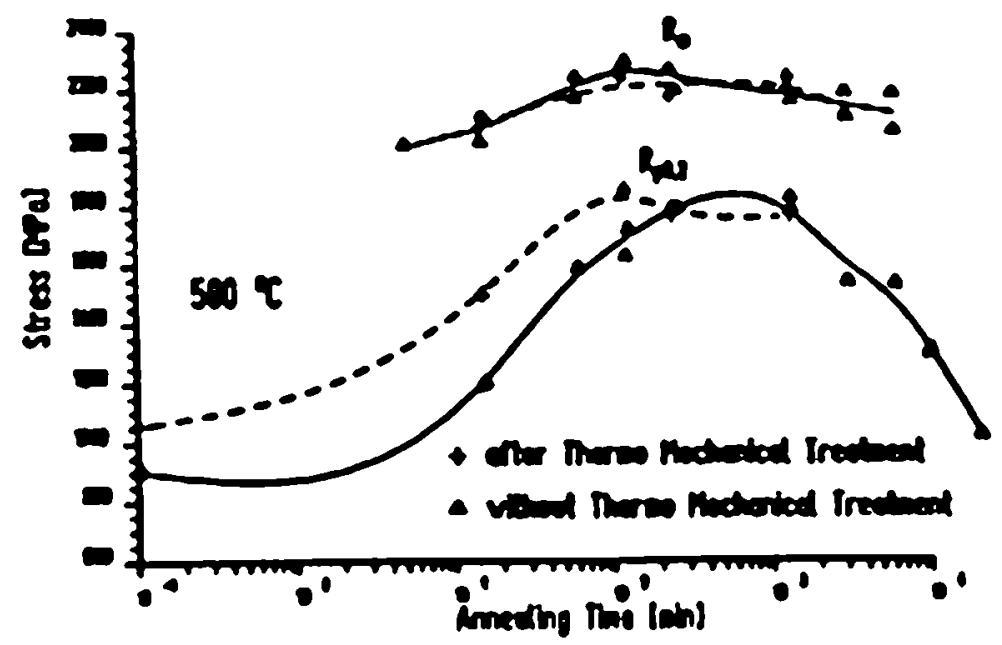

F18. 8: Influence of MMT on otrength in compresolon test with asolng tim.

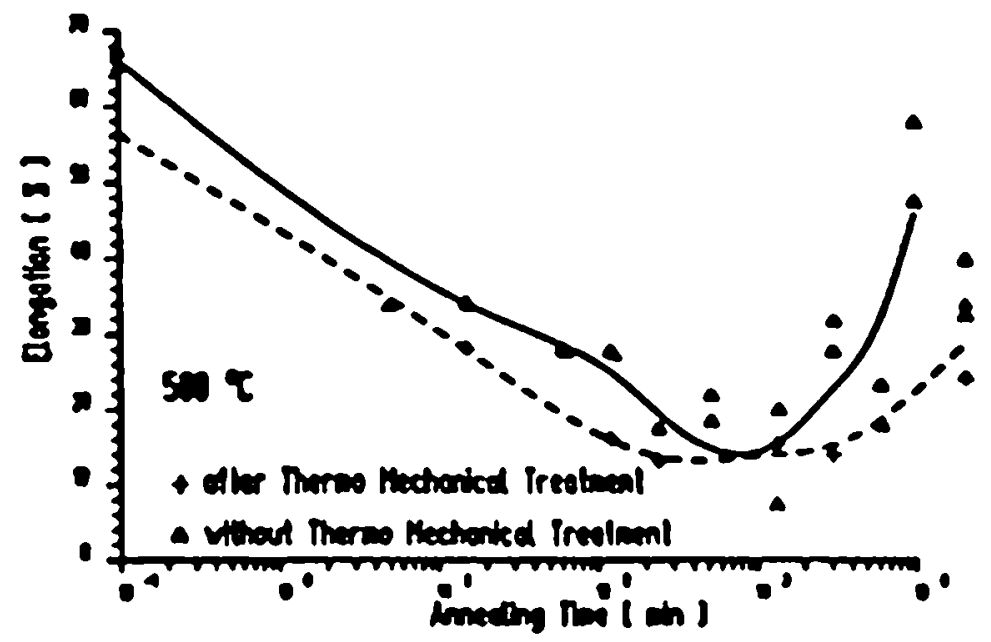

F18. 9: Influence of TMT on elongation In compresslon test with egeing tiac 


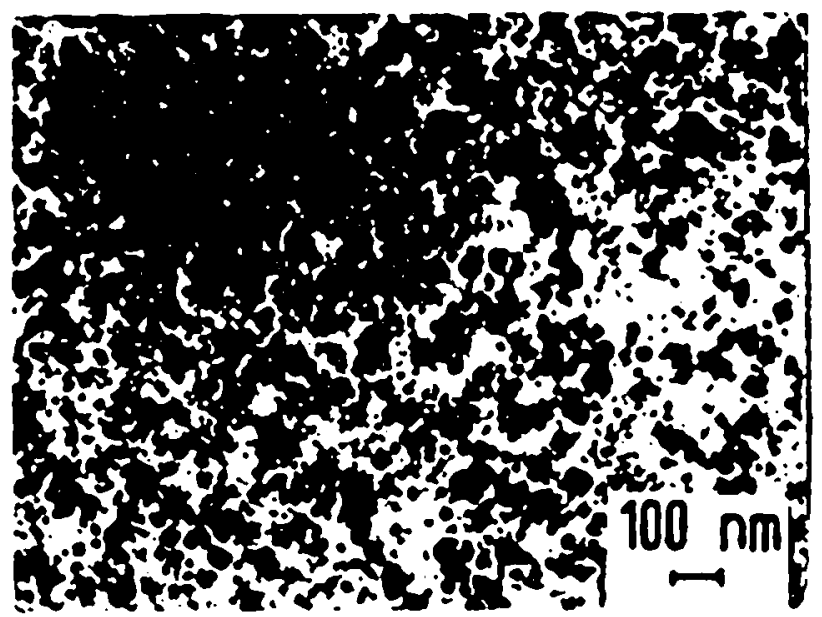

F18. 10 : Extraction replica, G-Phase $(\mathrm{Fe}, \mathrm{NL})_{16} \mathrm{TI}_{8} \mathrm{SL_{6 }}$

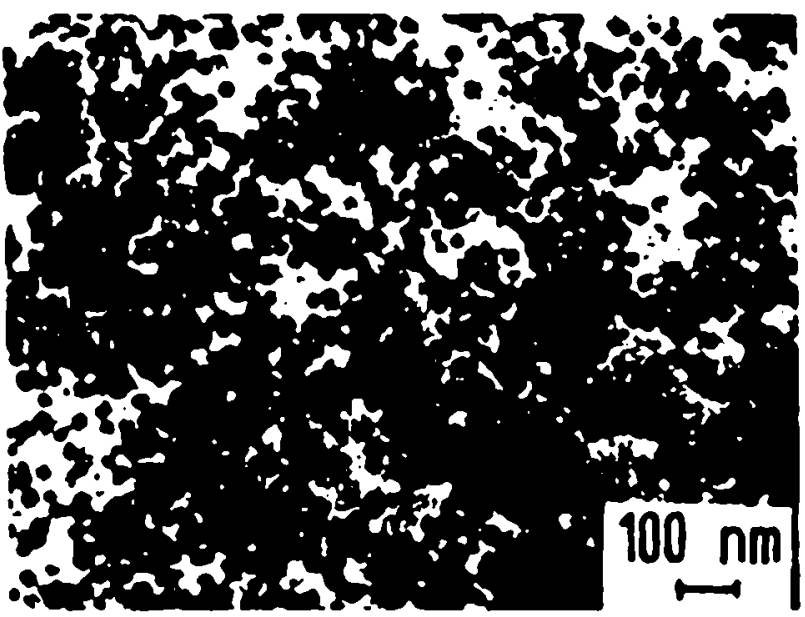

F18. 11 : Extraction repl Ica,Fe SITL spheroldal worphology

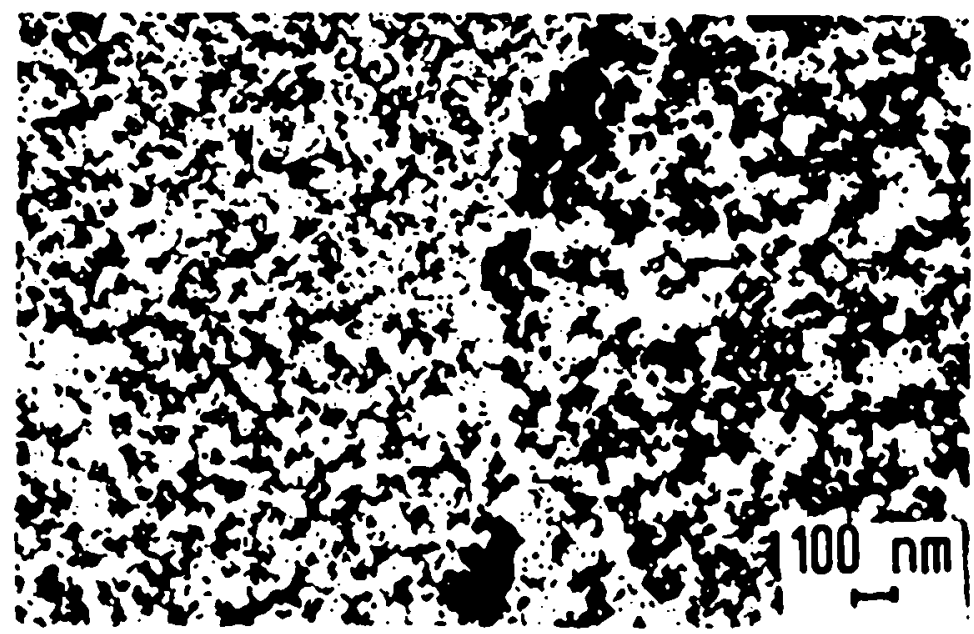

F1g. 12: G-Phase particles of two diffrently orlenated gralns, extr. replica

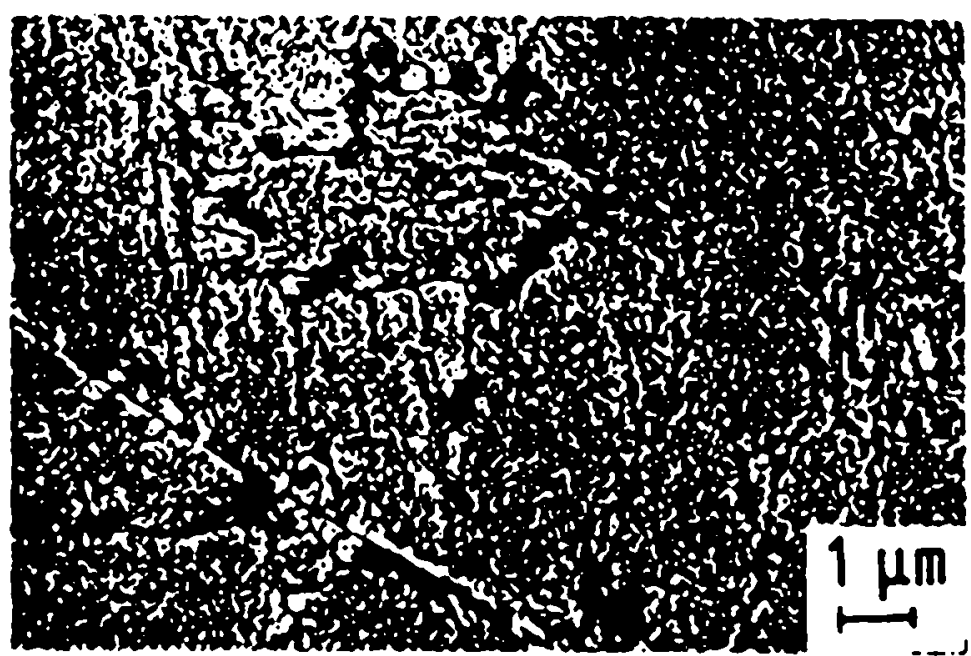

F18. 13: Extraction replica, showling coarse preclpltates on grain- and packet boundarles 
the overaged condltion after 95 hours the averago partlcle's olze 18 otlll only 8 ne but thelr shape is sore expliced cuboldal. Even in the coopletely orerased state the preclpltates are porfectly coherent to the eatrix and no traces of straln contrast were round. At pak hardness tho preclpltates show. eren in dark fleld lasge, no dlatinct phase boundarles, whlle thelr diffraction paterns can be clearly dlotingulshed. One rosoon cen be, that in thlo state or the prectpltation process there are ordered zonea or phases wlth the conposition $\mathrm{HI}_{2}$ TISt as were postulated by Utounowlya $/ 5 /$ or nuolell of $50_{3} \mathrm{SI}$ Incorporating Tl atcas as supposed by Brown /6/ in Fe-si-Tl alloys.

\section{Sumary}

Preclpltation of ordered. coherent. Iinly disparsed prectpltates produce a algnlfelcant ace-hardenls. Inls ls connected with a lass of ductilsty, cawed by Inhomogeneous ollp, which glves slip bands. foraed by prevlows anearine of the coherent particles. In return, overaged apoelcons have an acceptable proof strength of $1800 \mathrm{MPa}$ as woll a oultade duotllfty. In thls otate tho proolpltates are ot 111 very small wlth o damoter 1000 than $10 \mathrm{~nm}$ and the plastlo flow may be controlod by Orowan bowing of dislocatlons between preolpltetes.

\section{Llterature}

/IRLIedel, H. B Dr.-Thests, RuTH Machen, 1983

121 Jack. D.K. \& Honeycoobe. R.H.K, Acte Hot.. 1972, 20,0. 787

/3/ Beatle, H.J.8 Hagel. H.C. \& Trans. Metall. SOC. ADE 209 (1957). D. 911

14/ Bower. E.N. \& mittean, J.A.\& Effect of Second-Phase Parlicleo on the Mechantcal Propertles of Steel. Scarborough, (1971). D. 143-152

151 Utounomlya. T.I Hoshlno, K. I Effects of Slllcon and Titanlua on Hochanlcal Propertles and Proolpltation Bohovior of 15Cr-7X1 Martensitlo Stainless Steels, ASH Intern. Conf. on Stalniess Steel, Dotrolt. Michican, USA: 17-20 Sept. 1984

16/ Broun, C.C.8 unttean, J.A.8 J. Aust. Inst. Metals, 1969, 14. D. 217-227 